\section{Regards sur l'économie allemande}

Bulletin économique du CIRAC

$67 \mid 2004$

Varia

\title{
Formation et emploi
}

GRÜNEWALD Uwe et al. (eds), Betriebliche Weiterbildung in Deutschland und Europa / FROMMBERGER Dietmar, Kaufmännische Berufsbildung im europäischen Ländervergleich / TEICHLER Ulrich, Hochschule und Arbeitswelt. Konzeptionen, Diskussionen, Trends

\section{OpenEdition}

\section{Journals}

Édition électronique

URL : http://journals.openedition.org/rea/3822

DOI : $10.4000 /$ rea.3822

ISBN : 978-2-8218-0830-0

ISSN : 1965-0787

Éditeur

CIRAC

Édition imprimée

Date de publication : 1 juillet 2004

ISSN : 1156-8992

Référence électronique

«Formation et emploi », Regards sur l'économie allemande [En ligne], 67 | juillet 2004, mis en ligne le 08 octobre 2009, consulté le 22 septembre 2020. URL : http://journals.openedition.org/rea/3822 ; DOI : https://doi.org/10.4000/rea.3822

Ce document a été généré automatiquement le 22 septembre 2020.

(c) CIRAC 


\section{Formation et emploi}

GRÜNEWALD Uwe et al. (eds), Betriebliche Weiterbildung in Deutschland und Europa / FROMMBERGER Dietmar, Kaufmännische Berufsbildung im europäischen Ländervergleich / TEICHLER Ulrich, Hochschule und Arbeitswelt. Konzeptionen, Diskussionen, Trends

\section{RÉFÉRENCE}

GRÜNEWALD Uwe et al. (eds), Betriebliche Weiterbildung in Deutschland und Europa, Bundesinstitut für Berufsbildung, Bonn, 2003, 202 p. FROMMBERGER Dietmar, Kaufmännische Berufsbildung im europäischen Ländervergleich, Coll. Bildung und Arbeitswelt, vol. 10, Nomos Verlagsgesellschaft, Baden-Baden, 2004, 380 p.

TEICHLER Ulrich, Hochschule und Arbeitswelt. Konzeptionen, Diskussionen, Trends, Campus Verlag, Francfort/New York, 2003, 274 p.

1 La question des qualifications est au cœur du débat sur la compétitivité allemande (voir REA 66/04), suscitant un regain d'intérêt pour les études comparatives européennes, qu'il s'agisse de la formation initiale aux professions commerciales (FROMMBERGER) ou des systèmes de formation continue en entreprise (GRUNEWALD et al.). Et bien que les universités allemandes soient traditionnellement proches du tissu économique, il se pose outre-Rhin la question de l'adéquation des cursus et qualifications dispensées à un monde professionnel en mutation (TEICHLER). (IB) 